\section{Trial of human diploid cell rabies vaccine in human volunteers}

Preliminary studies of a recently developed human diploid cell vaccine (HDCV) against rabies showed that it gave good protection to animals. ${ }^{1}$ Since the vaccine produced a high level of antibodies in the pre-exposure treatment of human volunteers, ${ }^{2-5}$ trials were initiated in Aurangabad and Bombay, both areas where rabies is endemic, as a first step to determine whether it might be an alternative to the Semple vaccine for the postexposure treatment of rabies.

\section{Patients, methods, and results}

HDCV was prepared in WI-38 human fibroblasts and supplied in lyophilised form by the Institut Merieux (Lyon, France). The vaccine was reconstituted with distilled water and had an antigenic value of about 3 . HDVC $(4 \mathrm{ml})$ was injected into the deep subcutaneous tissue of the upper arm of volunteers in one of two dosage schedules. Group 1 (18 volunteers) received $1 \mathrm{ml}$ vaccine each on days $0,3,7$, and 14 ; group 2 (23) received $2 \mathrm{ml}$ vaccine each on days 0 and 10 . Semple type vaccine, a heat- and phenolinactivated emulsion of brains from rabies-infected sheep, supplied by the Haffkine Institute, Bombay, was given to 30 patients attending the antirabic treatment centre at the Medical College Hospital, Aurangabad, after being bitten by dogs in 14 daily injections of 5 or $10 \mathrm{ml}$ into the deep subcutaneous tissue of the abdominal wall. In group 3 (23) rabies infection was not proved; in group $4(7)$ the dog was proved rabid.

There were few reactions to HDCV. Seven volunteers complained of local pain and swelling, usually after the fourth injection of $1 \mathrm{ml}$. No reactions were reported among those who received two inoculations of $2 \mathrm{ml}$ of vaccine (group 2). One volunteer in group 1 developed local pain and swelling with high fever lasting 48 hours after each of the two doses of HDCV. Reactions among patients receiving Semple vaccine were not recorded. The level of virus neutralising antibody at different times after HDCV vaccination was similar in both schedule groups (see table). Ten days after the first inoculation all volunteers in group 1 , and all but one in group 2 had detectable antibodies. When sera were tested three months after the beginning of vaccination the antibody level had decreased, but the residual levels were still high. Only seven of 21 patients sampled from groups 3 and 4 who were exposed to rabies and treated with Semple type brain vaccine had detectable antibodies on the day they received the 10th daily inoculation. Patients from group 4 showed higher antibody levels than those of group 3, even though they were treated with the same vaccine and by an identical immunisation schedule. Possibly the rabies virus-infected saliva entering the body of the exposed person acted as an additional antigen and was responsible for increased antibody production.

Comparison of rabies virus neutralising antibody titres* in persons immunised with human diploid cell vaccine $(H D C V)$ and persons treated after exposure to rabies zith Semple brain tissue vaccine. Results are geometric mean titres

\begin{tabular}{|c|c|c|c|c|}
\hline \multirow{2}{*}{$\begin{array}{c}\text { Day after } \\
\text { inoculation }\end{array}$} & \multicolumn{2}{|c|}{ HDCV } & \multicolumn{2}{|c|}{ Semple } \\
\hline & $\begin{array}{c}\text { Group } 1 \\
(n=18)\end{array}$ & $\begin{array}{c}\text { Group } 2 \\
(\mathbf{n}=23)\end{array}$ & $\begin{array}{c}\text { Group } 3 \\
(n=23)\end{array}$ & $\underset{\substack{\text { Group } 4 \\
(n=7)}}{4}$ \\
\hline $\begin{array}{r}0 \\
10 \\
14 \\
30 \\
90\end{array}$ & \begin{tabular}{|r|}
$<0.1$ \\
$1.0(0 \cdot 1-25 \cdot 0)$ \\
$3.9(0 \cdot 3-30 \cdot 0)$ \\
$4.6(0.9-30 \cdot 0)$ \\
$1.8(0 \cdot 3-12 \cdot 0)$
\end{tabular} & \begin{tabular}{|c|}
$<0 \cdot 1$ \\
$0.6(0 \cdot 1-18 \cdot 0)$ \\
$3 \cdot 5(0 \cdot 9-25 \cdot 0)$ \\
$3 \cdot 0(0 \cdot 3-60 \cdot 0)$ \\
$2 \cdot 0(0 \cdot 3-44 \cdot 0)$
\end{tabular} & \begin{tabular}{|c|}
$<0.1$ \\
$0.1(<0 \cdot 1-3 \cdot 1)$ \\
$0.4(0.2-6 \cdot 2)$ \\
$0.5(0.2-2 \cdot 5)$
\end{tabular} & \begin{tabular}{|c|}
$<0 \cdot 1$ \\
$0.1(0 \cdot 1-3 \cdot 1)$ \\
$4 \cdot 6(3 \cdot 2-18 \cdot 7)$ \\
$1.5(0 \cdot 1-12 \cdot 5)$
\end{tabular} \\
\hline
\end{tabular}

*Virus neutralising antibody levels were determined by plaque reduction technique, and are expressed in International Units (IU). Standard $\mathrm{NIH}$ rabies antibody of $1 / 160$.

\section{Discussion}

These trials showed that a two- or four-dose schedule of HDCV could give an antibody response equal to that of 14 doses of Semple vaccine and, in addition, the antibody response to HDCV in most volunteers seemed to develop faster. On the basis of early antibody development at $\mathbf{1 0}$ days the four-dose schedule must be considered better than the two-dose schedule. Judged by the criterion of antibody development by the 10th day the Semple vaccine performed poorly.

Although no definite correlation has yet been found between neutralising antibody levels in the blood after post-exposure treatment and protection against the disease, preliminary tests in animals ${ }^{5}$ indicate that one to three inoculations of HDCV can protect animals if treatment is started several hours after contact with street rabies virus. If further study confirms these results, it should be possible to offer the tissue culture vaccine to people requiring protection against rabies as an alternative to Semple vaccine with fewer injections.
This investigation was supported in part by USPHS research grant AI-09706 from the National Institute of Allergy and Infectious Diseases, Contract No NIH-71-2292 with the National Institutes of Health, funds from the World Health Organisation, and funds from the Merieux Institute, Lyon, France. We are indebted to Mrs Doris Grella and Ms Meryl Harrison for excellent technical help.

Requests for reprints should be addressed to Dr Stanley A Plotkin, The Wistar Institute, 36th Street at Spruce, Philadelphia, Pa 19104, USA.

1 Wiktor, T J, et al, fournal of Infectious Diseases, 1972, 126, 408.

2 Wiktor, T J, Plotkin, S A, and Grella, D W, fournal of the American Medical Association, 1973, 224, 1170.

${ }^{3}$ Bahmanyar, M. (Teheran). Symposia Series in Immunological Standardization, 1974, 21, 226.

${ }^{4}$ Aoki, F Y, Tyrrell, D A J, and Hill, L E, Lancet, 1975, 1, 660.

5 Wiktor, T J, et al, Fournal of Infectious Diseases, in press.

\section{Aurandabad Medical College, Aurangabad, India}

USHA SHAH, $\cdot$ MD, professor (present address: B J Medical College, Poona, India)

G S JASWAL, MD, lecturer

The Haff kine Institute, Bombay, India

H J MANSHARAMANI, MD, scientific officer

Wistar Institute of Anatomy and Biology, World Health Organisa-

tion Collaborative Centre for Reference and Research in Rabies, Philadelphia, Pennsylvania 19104

S A PLOTKIN, MD, member

T J WIKTOR, DVM, member

\section{Neonatal appendicitis}

Acute appendicitis in a neonate is rare. I describe a case in a 2-weekold baby.

\section{Case report}

A girl, born at full term on 6 February 1975, was admitted to the British Military Hospital, Munster, on 21 February 1975. She was bottle-fed, and had no feeding problems up to the day before admission. She refused her evening feed on 20 February, and during the night vomited yellow material and passed loose green faeces. She continued to refuse feeds. On admission she was apyrexial, not dehydrated, with a moderately distended soft abdomen and active bowel sounds. Bile-stained vomiting continued over the next 24 hours, but then vomiting became faeculent. She was still apyrexial, but the abdomen was more distended and the rectum empty. Erect and supine abdominal $x$-ray films showed small-bowel distension with fluid levels.

Laparotomy was performed 52 hours after the initial symptoms. The peritoneal cavity contained turbid fluid, and the dilated small bowel was coated with purulent exudate. A kinked loop of ileum, adherent to the ileocaecal region, was causing the obstruction. Further dissection showed an acutely inflamed gangrenous appendix. Routine appendicectomy with stump burial was performed. Peritoneal fluid culture grew predominantly Klebsiella spp. Pathological examination confirmed acute inflammatory changes, but no perforation. Postoperatively she was treated with gentamicin and benzylpenicillin. Recovery was uneventful, and she was discharged on the eighth day.

\section{Discussion}

Appendicitis in the neonate is rare. In 1960 Schaupp et al ${ }^{1}$ reviewed reports published in the English-speaking world and found only 19 cases, to which they added five of their own. Only four of these babies survived-a mortality rate of $83^{\circ} \%$. Since then 19 cases have been reported (making a total of 43 cases). Eight of these survived, giving a total mortality rate of $70^{\circ}$.

The authors all emphasise the difficulty of diagnosis. The presenting symptoms are usually non-specific-anorexia, vomiting, and diarrhoea. Signs likewise are all too often unhelpful-dehydration and minor degrees of abdominal distension. Fever is often absentHardman and Bowerman ${ }^{2}$ found this in 11 out of 16 cases. They also found a raised white cell count present in only five out of nine 